\title{
A Case of Cell-Free and Concentrated Ascites Reinfusion Therapy Effective for Refractory Ascites in Spontaneous Bacterial Peritonitis in a Renal Transplant Patient
}

\author{
Atsuhiro Maeda ${ }^{a}$ Kazuhito Takeda ${ }^{a}$ Kazuhiko Tsuruya ${ }^{b}$ \\ Shuuhei Miura $^{a}$ Jirou Toyonaga $^{a}$ Satsuki Nakashita ${ }^{a}$ \\ Masahide Furushou $^{a}$ Hideyuki Mukai $^{\mathrm{a}}$ \\ Yoshiharu Mutou $^{a}$ Tomo Komaki $^{\text {a }}$ Keita Takae $^{a}$ \\ Chikao Yasunaga ${ }^{\mathrm{C}}$ \\ ${ }^{a}$ Department of Nephrology and Kidney Center, Aso-lizuka Hospital, lizuka, \\ ${ }^{b}$ Department of Medicine and Clinical Science, Graduate School of Medical \\ Sciences, Kyushu University, Fukuoka, and 'Department of Kidney Center, \\ Saiseikai Yahata General Hospital, Kitakyushu, Japan
}

\section{Key Words}

Acute renal failure - Cell-free and concentrated ascites reinfusion therapy - Refractory ascites $\cdot$ Renal transplantation $\cdot$ Spontaneous bacterial peritonitis

\begin{abstract}
A 58-year-old Japanese male with chronic hepatitis $C$ underwent kidney transplantation from an unrelated donor in October 1998. In December 2004, the patient was admitted for spontaneous bacterial peritonitis (SBP). Abdominal paracentesis and albumin transfusion were performed, but control of ascites was poor. A randomized, controlled study of patients with SBP showed that patients receiving cefotaxime with a high-volume albumin transfusion $(50-75 \mathrm{~g} / 50 \mathrm{~kg}$ ) were significantly less likely to have irreversible renal failure and had lower mortality. Japan, however, relies on imports for $70 \%$ of its albumin formulations, which complicates high-volume albumin transfusion. Consequently, albumin transfusion is often limited to single treatments in the range of only $25 \mathrm{~g}(25 \%, 100 \mathrm{ml})$. A single cell-free and concentrated ascites reinfusion therapy (CART) treatment can reinfuse approximately $60 \mathrm{~g}$ of
\end{abstract}


albumin, corresponding to a high-volume albumin transfusion capable of reducing the associated risk of infection or allergic reaction. Though this case was an SBP patient, after the ascites were found to be negative for endotoxins, CART was performed, and control of ascites was achieved without observation of fever, hypotension, or other adverse effects. CART provides greater supplementation of albumin than albumin transfusion and can be an effective modality of treatment for hypoalbuminemia in SBP patients if ascites are negative for endotoxins.

\section{Introduction}

Refractory ascites causes abdominal distention, abdominal pain and dyspnea and thereby aggravates patient quality of life and activities of daily living. The effect of abdominal paracentesis is temporary, but loss of albumin and globulin can cause deterioration of nutritional and immune status and lowered colloid osmotic pressure.

Cell-free and concentrated ascites reinfusion therapy (CART) is a treatment which maintains albumin and globulin by filtration, concentration, and reinfusion of drained ascites. The advantages of this method are that albumin transfusion can be employed sparingly, and the risk of infection or allergic reaction is thus reduced. However, CART is dangerous to spontaneous bacterial peritonitis (SBP) patients because inadvertent reinfusion of filtrated, concentrated endotoxins in ascites has caused adverse effects of temporary fever and shock.

We report our pursuit of CART for refractory ascites in SBP after finding that ascites were negative for endotoxins.

\section{Case Report}

A 58-year-old Japanese male with end-stage renal failure due to chronic glomerulonephritis and receiving chronic hemodialysis since 1980 underwent kidney transplantation from an unrelated donor in October 1998. This case was also complicated by chronic hepatitis C.

In January 2004, liver cirrhosis with a Child-Pugh score of 6 points (grade A) was diagnosed based on total serum bilirubin (T-bil) of $0.7 \mathrm{mg} / \mathrm{dl}$, serum albumin (S-alb) of $2.8 \mathrm{~g} / \mathrm{dl}$, prothrombin timeinternational normalized ratio (PT-INR) of 1.1, and medical control of ascites. During follow-up, serum creatinine (S-Cr) was $0.8 \mathrm{mg} / \mathrm{dl}$. Immunosuppressive therapy consisted of mycophenolate mofetil (500 mg/day), tacrolimus hydrate ( $2 \mathrm{mg}$ /day), and prednisolone ( $7.5 \mathrm{mg} /$ day). In November $2004,160 \mathrm{mg} /$ day furosemide and $4 \mathrm{mg} /$ day thiazide were administered for increased ascites, but the effect was insufficient.

On December 26, 2004, the patient was hospitalized for fever, abdominal pain, dyspnea, and copious ascites. On admission, patient height was $167.6 \mathrm{~cm}$, body weight $59.2 \mathrm{~kg}$, body temperature $39.2^{\circ} \mathrm{C}$, blood pressure $154 / 92 \mathrm{~mm} \mathrm{Hg}$, and pulse 72 beats/min. Physical examination found jaundice in the bulbar conjunctivae. The abdomen was diffusely tender with rigidity and rebound. There was no sign of hepatic encephalopathy. Medical history was unremarkable apart from immunosuppressants and diuretics. Table 1 presents the laboratory findings on admission, including a white blood cell count of 8,500/ $\mu \mathrm{l}$ and a C-reactive protein (CRP) level of $11.3 \mathrm{mg} / \mathrm{dl}$. Based on T-bil $2.6 \mathrm{mg} / \mathrm{dl}, \mathrm{S}$-alb $2.7 \mathrm{~g} / \mathrm{dl}$, PT-INR 1.1, and the presence of refractory ascites, liver cirrhosis with a Child-Pugh score of 9 points (grade B) was diagnosed. The ascites were exudative and demonstrated a specific gravity of 1.032 , total protein of $3.1 \mathrm{~g} / \mathrm{dl}$, total albumin of $1.6 \mathrm{~g} / \mathrm{dl}$, Rivalta's reaction positive, and polymorphonuclear leukocyte (PMN) count of 940 cells $/ \mathrm{mm}^{3}$. Renal failure was identified based 
on a blood urea nitrogen (BUN) level of $55 \mathrm{mg} / \mathrm{dl}$ and S-Cr of $2.3 \mathrm{mg} / \mathrm{dl}$. Tacrolimus trough concentration was not problematic, at $6.2 \mathrm{ng} / \mathrm{ml}$; urinalysis was also normal; fractional excretion of urea nitrogen (FeUN) was low, at $20 \%$; and on this basis, prerenal failure was diagnosed.

Abdominal computed tomography scan and abdominal ultrasound showed copious ascites, but there was no evidence of abscess, perforation, or penetration. Diagnosis of SBP was thus based on the clinical and laboratory findings. Several blood and ascites cultures did not demonstrate pathogenic organisms.

Fig. 1 presents the clinical course and treatment pursued. Immediately after ascites puncture, we began empirical antibiotic therapy with ceftriaxone intravenously $(1 \mathrm{~g} /$ day), and mycophenolate mofetil and tacrolimus hydrate were discontinued. Two days after initiation of treatment, body temperature was normal, and abdominal pain had ceased, but the copious ascites were not improved.

Abdominal paracentesis (3 l/day) and albumin transfusion (25\%, $100 \mathrm{ml} /$ day) were performed 6 times, but the effect was temporary, and control of ascites was poor. S-alb decreased to $1.8 \mathrm{~g} / \mathrm{dl}$, renal failure deteriorated, urinary volume declined, and ascites increased yet further. Due to normal urinalysis and low FeUN of 20\%, aggravation of prerenal failure was a suspected factor.

Because the PMN count in ascites decreased to 58 cells $/ \mathrm{mm}^{3}$ and ascites were also endotoxin negative $(0.8 \mathrm{pg} / \mathrm{ml})$, CART was initiated, with $3.0 \mathrm{l}$ of ascites filtrated and concentrated to $0.3 \mathrm{l}$ in 120 min. The concentrated fluid was drip-infused back into the patient at the rate of $0.15 \mathrm{l} / \mathrm{h}$. The apparatus used was the Plascit 01 and the columns used were model AHF-MOW for the ascites filtration and the model AHF-UNH for the ascites concentration, all manufactured by Asahi Kasei Medical (Tokyo, Japan).

At such time, S-alb rose gradually, and the level of ascites decreased. CART was performed a total of 6 times, and ascites were well controlled, with no observation of fever, hypotension, or other adverse effects. Biochemical results also improved to T-bil $0.7 \mathrm{mg} / \mathrm{dl}, \mathrm{S}-\mathrm{alb} 3.2 \mathrm{~g} / \mathrm{dl}$, BUN $37 \mathrm{mg} / \mathrm{dl}$, SCr $1.2 \mathrm{mg} / \mathrm{dl}$, and CRP $0.0 \mathrm{mg} / \mathrm{dl}$. No findings suggesting rejection of a transplanted kidney were observed, mycophenolate mofetil (500 mg/day) and tacrolimus hydrate ( $2 \mathrm{mg} /$ day) were reinitiated, and the patient was discharged.

\section{Discussion}

Peritonitis in immunosuppressed renal transplant recipients remains associated with high morbidity and mortality [1]. The diagnostic criteria for SBP are bacterial growth from the ascitic fluid plus an ascitic PMN count of more than $250 / \mu \mathrm{l}$, or ascitic fluid with a PMN count of more than $500 / \mu$ l, even in the absence of a positive culture [2]. In this case, SBP was diagnosed on the basis of an ascitic PMN count of 940 cells $/ \mathrm{mm}^{3}$ and the absence of an obvious intra-abdominal source of infection.

SBP is thought to result from a combination of factors inherent in cirrhosis and ascites, such as prolonged bacteremia secondary to compromised host defense, intrahepatic shunting of colonized blood, and defective bactericidal activity within the ascitic fluid [3]. Some $40 \%$ to $50 \%$ of all patients with SBP have negative cultures of both blood and ascitic fluid, as in this case $[4,5]$.

Since the 1985 seminal study, which showed better outcomes with cefotaxime than with the combination of ampicillin and tobramycin, third-generation cephalosporins have been the agents of choice in the management of SBP. Subsequently, several studies have reinforced the role of third-generation cephalosporins in an effort to determine the optimal dose and duration of therapy [5-9].

Guidelines for SBP have been published by The International Ascites Club and suggest several antibiotics that may be used for empirical treatment, including 
cefotaxime, cefonicid, ceftizoxime, ceftriaxone, ceftazidime, and amoxicillin-clavulanic acid [10]. Based on the reports cited, we selected ceftriaxone, and given the prerenal failure status, dosage was reduced to $1 \mathrm{~g} /$ day. This treatment achieved a good therapeutic effect.

Acute renal failure develops in 33\% of patients with SBP and is a major cause of death [11]. After abdominal paracentesis, intravenous infusion of albumin has been used to avoid reduction of the effective volume and prerenal failure $[12,13]$. A randomized, controlled study of patients with SBP showed that patients receiving cefotaxime with a high-volume albumin transfusion (1.0-1.5 g/kg) were significantly less likely to have irreversible renal failure and had lower mortality [14]. Japan, however, relies on imports for $70 \%$ of its albumin formulations, which complicates high-volume albumin transfusion (e.g., $1.0-1.5 \mathrm{~g} / \mathrm{kg}$ ).

CART is a treatment which maintains albumin and globulin by filtration, concentration, and reinfusion of drained ascites. A single CART treatment reportedly can reinfuse approximately $60 \mathrm{~g}$ of albumin, and this amount corresponds to a highvolume albumin transfusion capable of reducing the associated risk of infection or allergic reaction [15]. However, CART is more expensive than the high volume of albumin transfusion ( $60 \mathrm{~g}$ ) in Japan (90,000 vs. 60,000 yen).

CART cannot eliminate endotoxins, which present a danger to SBP patients as a risk of endotoxin shock or temporary fever. SBP is deemed resolved when all signs of infection have disappeared and the ascitic fluid PMN count is below 250 cells $/ \mathrm{mm}^{3}$ [4]. In our case, CART was pursued after the PMN count in ascites decreased to 58 cells $/ \mathrm{mm}^{3}$ and the ascites were found to be endotoxin negative. At such time, no shock or temporary fever was observed. Though administration of prednisolone $(7.5 \mathrm{mg} /$ day $)$ as immunosuppressive therapy may have prevented occurrence of a temporary fever, we believe that CART is a safe treatment even for endotoxin-negative SBP patients.

\section{Disclosure Statement}

There are no financial disclosures. 
Table 1. Laboratory findings on admission

\begin{tabular}{|c|c|}
\hline \multicolumn{2}{|l|}{ Urinalysis } \\
\hline Protein & - \\
\hline Glucose & - \\
\hline Occult blood & - \\
\hline Bilirubin & - \\
\hline \multicolumn{2}{|l|}{ Blood cell count } \\
\hline White blood cells, $/ \mu \mathrm{l}$ & 8,500 \\
\hline Hematocrit, \% & 31.9 \\
\hline Hemoglobin, g/dl & 10.8 \\
\hline Red blood cells, $\times 10^{4} / \mu \mathrm{l}$ & 337 \\
\hline Platelets, $\times 10^{4} / \mu \mathrm{l}$ & 9.2 \\
\hline \multicolumn{2}{|l|}{ Coagulation test } \\
\hline PT-INR & 1.10 \\
\hline Activated partial thromboplastin time, s & 38.5 \\
\hline \multicolumn{2}{|l|}{ Blood chemistry } \\
\hline Total protein, g/dl & 5.3 \\
\hline $\mathrm{Alb}, \mathrm{g} / \mathrm{dl}$ & 2.7 \\
\hline Aspartate aminotransferase, $\mathrm{U} / \mathrm{l}$ & 53 \\
\hline Alanine aminotransferase, $\mathrm{U} / \mathrm{l}$ & 32 \\
\hline Lactate dehydrogenase, $\mathrm{U} / \mathrm{l}$ & 521 \\
\hline Alkaline phosphatase, $\mathrm{U} / \mathrm{l}$ & 488 \\
\hline$\gamma$-Glutamyl transpeptidase, $\mathrm{U} / \mathrm{l}$ & 478 \\
\hline Cholinesterase, $\mathrm{U} / \mathrm{l}$ & 113 \\
\hline $\mathrm{T}-\mathrm{bil}, \mathrm{mg} / \mathrm{dl}$ & 2.6 \\
\hline BUN, mg/dl & 55 \\
\hline $\mathrm{Cr}, \mathrm{mg} / \mathrm{dl}$ & 2.3 \\
\hline $\mathrm{Na}, \mathrm{mEq} / \mathrm{l}$ & 134 \\
\hline $\mathrm{K}, \mathrm{mEq} / \mathrm{l}$ & 4.0 \\
\hline $\mathrm{Cl}, \mathrm{mEq} / \mathrm{l}$ & 100 \\
\hline CRP, mg/dl & 11.3 \\
\hline \multicolumn{2}{|l|}{ Serological study } \\
\hline Hepatitis B virus antigen & - \\
\hline Hepatitis $C$ virus antibody & + \\
\hline \multicolumn{2}{|l|}{ Ascitic fluid analysis } \\
\hline Color & yellow \\
\hline Turbidity & cloudy \\
\hline Leukocytes, cells $/ \mathrm{mm}^{3}$ & 940 \\
\hline Specific gravity & 1.032 \\
\hline Total protein, g/dl & 3.1 \\
\hline $\mathrm{Alb}, \mathrm{g} / \mathrm{dl}$ & 1.6 \\
\hline Bacterial culture & negative \\
\hline Rivalta's reaction & positive \\
\hline \multicolumn{2}{|l|}{ Others } \\
\hline$\alpha$-Fetoprotein, $\mathrm{ng} / \mathrm{ml}$ & 2.0 \\
\hline Child-Pugh score, points & 9 \\
\hline Tacrolimus trough concentration, $\mathrm{ng} / \mathrm{ml}$ & 6.2 \\
\hline
\end{tabular}




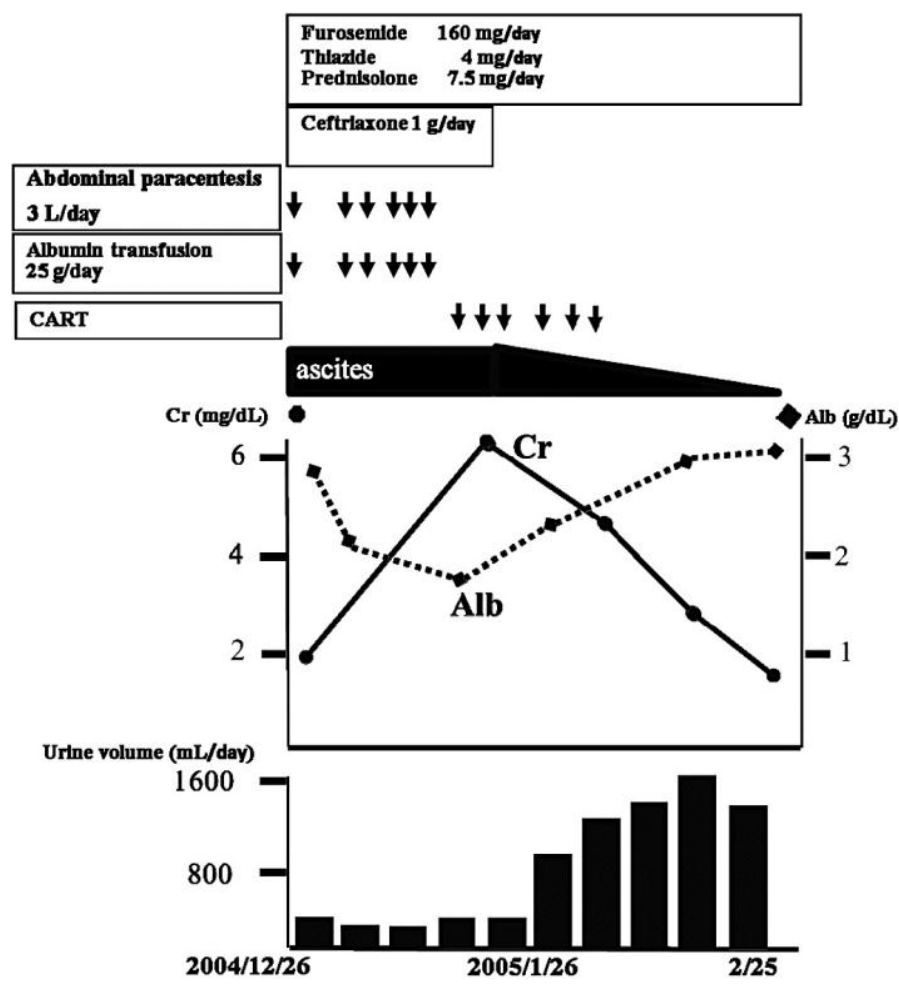

Fig. 1. Clinical course. We began empirical antibiotic therapy with ceftriaxone intravenously $(1 \mathrm{~g} /$ day). Abdominal paracentesis (3 l/day) and albumin transfusion $(25 \%, 100 \mathrm{ml} /$ day) were performed 6 times, but the effect was temporary, and control of ascites was poor. S-alb decreased to $1.8 \mathrm{~g} / \mathrm{dl}$, prerenal failure deteriorated, urinary volume declined, and ascites increased yet further. Because the PMN count in ascites decreased to 58 cells $/ \mathrm{mm}^{3}$ and ascites were also endotoxin negative, CART was initiated, with $3.0 \mathrm{l}$ of ascites filtrated and concentrated to $0.3 \mathrm{l}$ in $120 \mathrm{~min}$. At such time, S-alb rose gradually, and the level of ascites decreased. CART was performed a total of 6 times, and ascites were well controlled, with no observation of fever, hypotension, or other adverse effects. Biochemical results also improved to S-alb $3.2 \mathrm{~g} / \mathrm{dl}$ and S-Cr $1.2 \mathrm{mg} / \mathrm{dl}$, and the patient was discharged.

\section{References}

-1 Ekmekci Y, Sengul S, Kutlay S, Azap A, Tuzuner A, Erbay B: Klebsiella pneumoniae peritonitis shortly after kidney transplantation. Transplant Proc 2005;37:2122-2123.

-2 Mihas AA, Toussaint J, Hsu HS, Dotherow P, Achord JL: Spontaneous bacterial peritonitis in cirrhosis: clinical and laboratory features, survival and prognostic indicators. Hepatogastroenterology 1992;39:520-522.

-3 Runyon BA, Hoefs JC: Culture-negative neutrocytic ascites: a variant of spontaneous bacterial peritonitis. Hepatology 1984;4:1209-1211.

4 Franca AVC, Giordano HM, Seva-Pereira T, Soares EC: Five days of ceftriaxone to treat spontaneous bacterial peritonitis in cirrhotic patients. J Gastroenterol 2002;37:119-122.

5 Rimola A, Salmeron JM, Clemente G, Rodrigo L, Obrador A, Miranda MJ, Guarner C, Planas R, Sola R, Vargas V, Casafont F, Marco F, Navasa M, Banares R, Arroyo V, Rodes J: Two different dosages of cefotaxime in the treatment of spontaneous bacterial peritonitis in cirrhosis: results of a prospective, randomized, multicenter study. Hepatology 1995;21:674-679.

6 Runyon BA, McHutchinson JG, Antillon MR, Akriviadis EA, Montano AA: Short-course versus long-course antibiotic treatment of spontaneous bacterial peritonitis: a randomized controlled trial of 100 patients. Gastroenterology 1991;100:1737-1742. 
7 Mercader J, Gomez J, Ruiz J, Garre MC, Valdes M: Use of ceftriaxone in the treatment of bacterial infections in cirrhotic patients. Chemotherapy 1989;35:23-26.

8 Gomez-Jimenez J, Ribera E, Gasser I, Artaza MA, Valle OD, Pahissa A, Martinez VJM: Randomized trial comparing ceftriaxone with cefonicid for treatment of spontaneous bacterial peritonitis in cirrhotic patients. Antimicrob Agents Chemother 1993;37:1587-1592.

-9 Mesquita MA, Balbino EPS, Albuquerque RS, Carmona CA, Okubo BT, Lorena SLS, Montes CG, Soares EC: Ceftriaxone in the treatment of spontaneous bacterial peritonitis: ascitic fluid polymorphonuclear count response and short-term prognosis. Hepatogastroenterology 1997;44:1276-1280.

$\$ 10$ Rimola A, Garcia-Tsao G, Navasa M, Piddock LJV, Planas R, Bernard B, Inadomi JM: Diagnosis, treatment and prophylaxis of spontaneous bacterial peritonitis: a consensus document. J Hepatol 2000;32:142153.

11 Follo A, Llovet JM, Navasa M, Planas R, Forns X, Francitorra A, Rimola A, Gassull MA, Arroyo V, Rodes J: Renal impairment after spontaneous bacterial peritonitis in cirrhosis: incidence, clinical course, predictive factors and prognosis. Hepatology 1994;20:1495-1501.

-12 Salerno F, Badalamenti S, Lorenzano E, Moser P, Incerti P: Randomized comparative study of Hemaccel vs albumin infusion after total paracentesis in cirrhotic patients with refractory ascites. Hepatology 1991;13:707-713.

13 Haynes GR, Navickis RJ, Wilkes MM: Albumin administration - what is the evidence of clinical benefit? A systematic review of randomized controlled trials. Eur J Anaesth 2003;20:771-793.

-14 Sort P, Navasa M, Arroyo V, Aldeguer X, Planas R, Ruiz-Del-Arbol L, Castells L, Vargas V, Soriano G, Guevara M, Gines P, Rodes J: Effect of intravenous albumin on renal impairment and mortality in patients with cirrhosis and spontaneous bacterial peritonitis. N Engl J Med 1999;341:403-409.

15 Graziotto A, Rossaro L, Inturri P, Salvagnini M: Reinfusion of concentrated ascitic fluid versus paracentesis. A randomized prospective trial. Dig Dis Sci 1997;42:1708-1714. 